\title{
Yoruba Girl Dancing and the Post-War Transition to an English Multi-Ethnic Society
}

\begin{abstract}
Helen Lock
This paper exemplifies the insider/outsider binary in a nation's shift towards a multi-ethnic society. The writer gives insight into the African Diaspora within England in her exploration of Yoruba Girl Dancing.
\end{abstract}

Simi Bedford's Yoruba Girl Dancing tells the story of Remi Foster, a small Nigerian girl who is uprooted in the early 1950s from her large and ebullient Yoruba family and transplanted to England. There she attends an exclusive English boarding school and spends vacations in suburbia with her step-grandmother's white relatives. Remi's is the story of a reluctant pioneer in the post-war process whereby urban England gradually became a multi-ethnic society and received the arrival of increasingly large numbers of former colonials. Yoruba Girl Dancing provides an illuminating picture of the transformations that took place at the beginning of this process-transformations that affected both the new and the established resident and the insider as well as the outsider. These transformations 
eventually would lead to a resistance and hardening of attitudes among the established population when previously imperceptible changes became more glaring as the trickle of newcomers swelled to a wave. For the earlier arrivals, however, the lines were less sharply drawn, and thus the experience more subtle.

Remi's story begins in Lagos with a portrait of the large and varied Foster household consisting of grandparents, nine foster children (the offspring of poor relations), assorted aunts and uncles with assorted prospects, three nannies, many servants, and Remi herself, who is on "permanent loan" from her parents as was the custom with the eldest grandchild (9). As the favorite of this warm and demonstrative family and the sole focus of the three nannies' attention, she leads a comparatively privileged existence, underwritten by her grandfather's wealth. While reveling in Yoruba culture and tradition, the household also has incorporated eclectic customs and values stemming from the influence of colonialism. The family adopted Christianity, and Remi explains, "Grandma hated heathenism. She said it was the mark of the savage and that superstitious practices by which we all knew she meant juju would on no account be tolerated in our house"(17). The family also absorbed European customs into traditional celebrations such as weddings and especially in their veneration for the value of an English education, many of the adults spending their college years in England. Hence the reluctance to wait for this favored child to reach adulthood: at six years old she leaves to experience the "great opportunity" of an English (45) boarding school education, escorted by her white step-grandmother, Bigmama (45).

From this point on the narrative focuses on Remi's experiences as the first black child everyone she encounters has met, the changes that occur in herself and others as she both attempts and resists assimilation, and her final recovery of a social identity as part of London's growing multi-ethnic community. The changes are what I want to focus on here, as they are indicative both of the mutual accommodations that have to be made in the formative years of a multi-ethnic community and the mutual benefits that can result. These mutual benefits last at least until flexibility begins to be perceived as a danger- 
ous weakness threatening a community's self-perception. In this telling of the story Remi's own transformation is ultimately a matter of accretion and expansion rather than diminishment-a journey toward, rather than from, a full and authentic identity.

Accustomed to the bustling heterogeneous Foster household, Remi finds it hard to adjust to the homogeneity of the English boarding school, where instead of being cosseted by nannies she is tyrannized by Matron. Remi is greeted by the other girls with curiosity fueled by misconceptions and/or ignorance. On meeting her roommates for the first time she says "Until now we could not have imagined each other"(84). Although this prejudice exists, the only open hostility comes from Anita, not on the grounds of race but through jealousy of Remi's instant celebrity. Anita is quick to exploit the racial issue, however: "'The black comes off,' she declared in a voice of doom. 'If you touch her the black will rub off on you and very soon you will be black all over too"'(86). Since this idea accords with all the children's preconceived notions of Africans and of blackness-it explains why Remi's palms are pink, for instance-it gains rapid currency until finally quashed by a French teacher. "I didn't blame Anita," says Remi, "in fact I could not help admiring her for the blackness trick, it was smart; had the situations been reversed and we had been in Lagos, I would have done the same and so would Yowande" (88).

Remi encounters similar problems among the workingclass children with whom she plays during vacations. They invite her to join their gang in order to "lend a unique authenticity to the Tarzan games which were played . . . after Saturday morning pictures. Gerald, who is part of the gang, says to her with kind intentions

Just think, we would have the real thing, a genuine African savage. When the occasion demanded it, I could double up as a Red Indian, savages being the same the world over. You'd like that; wouldn't you? (89-90)

Not very much, it turns out: the hapless native bearers she is called upon to play seem "exasperatingly accidentprone...'they've lived all their lives in the jungle, you'd think 
they'd have learnt a few tricks by now,' and she is baffled as to why Tarzan would rather live among animals than with the "darkies," although Gerald reassures her, "It's just that English people are daft about animals, everyone knows that $(116,117$, 90)."

Her problem, then, in school and out, is to change the other children's perceptions of her and of Africans in general. She does this by a skillful manipulation of the class differences between the two groups, using what she has learned from one group to reinvent herself in the eyes of the other. She projects in each case an identity that is no more authentic than the one they have projected upon her, but is at least self-generated. She begins to take control, in other words, of her environment and the role she is prepared to play in it with the limited options available. At school, for example, once past Anita's "blackness trick," she takes advantage of the fact that no one else at Chilcott Manor does anything so proletarian as attend Saturday morning pictures. She finds that the Tarzan films that only she has seen "prove[s] invaluable" in creating an identity for herself that simultaneously appeals to her listeners' innate snobbery and makes blackness exotically appealing rather than threatening:

By and by my father metamorphosed into a tribal chieftain whose frequent duty it was to leave his house in Lagos in order to make ceremonial visits to his ancestral village deep in the heart of the jungle.... Papa would have been amazed to hear, as I sat by the fire toasting crumpets, how frequently he led his villagers out on a leopard hunt with only his spear to protect him. Mama, Grandma, and Patience would have been equally astounded to hear that only the day before they had been sitting in the open around a snake stew supper (91).

Gradually the other girls are drawn to share the fantasy"No-one else could match the glamour and excitement of my games"-and revise their impressions of "Darkest Africa" which Remi has convinced them is really "blindingly bright and sunny"(94). (Ironically, she has dispelled their notions of savagery by reinventing her family as precisely the kind of Africans that her Nigerian grandmother would have considered to be 


\section{Ethnic Studies Review Volume 22}

savages.) Finally after a showdown with Estelle from South Africa, who asserts, "Africans were only employed as servants and she did not believe that my grandfather could possibly have had Europeans working for him," even Anita concurs with Remi's view. "I believe Remi, she's the one who really comes from Africa, she should know"'(194, 95). Remi's exotic version of Africa has become for them the "real" Africa, a no less distorted view than their original preconceptions, but at least one in which Remi's background is valorized, enabling her to function on socially equal terms and one that she has determined herself. As Adrienne Rich contends, "The relationship to more than one culture ... is a constant act of self-creation"(Rich 35$)$.

Remi's strategy with the gang in Thornton Heath is rather the reverse: her imagination is precisely what she withholds. Drawing on the kind of social authority she has been exposed to at school, she brings the Tarzan games to an end-the fearless native bearer kills a charging rhino with her spear, which is not in the script. Remi also refuses further participation in the gang until they adopt new games in which she and the smallest child, Wilf, play parts equal to the others. As the gang has come to rely on her creativity in supplying the refinements of their games, they capitulate and agree to substitute games of King Arthur and Martians from Outer Space. "[Wilf] and I both knew that he would never be King Arthur but he could be a knight which all the books said was a noble thing to be, and, as for Martians, well there was no reason for Doreen to look in my direction. Martians, as everybody knew, were green"(121). Here again her strategy reverses the one used at school: instead of investing the role of the Other, which she is compelled to play, with kudos and authority, here she divests herself of that role altogether, deflecting it onto an even more alien Other.

Remi's survival among these English children, then, forces her to take control of and make changes in the way she is perceived, while her very presence forces the adults she encounters to make changes of their own. The music teacher who immediately assigns her to the school choir, for example, is finally forced to acknowledge that Remi is tone-deaf and that not all people of color can sing as well as Paul Robeson. Her white relatives, too, have to re-evaluate their position with 
respect to the rest of society, especially on a seaside holiday when they virtually compel Remi to go out on the beach and "enjoy herself," and she becomes the object of taunts from children and intrusive curiosity from adults. As a result of having their family suddenly become the focus of unwelcome scrutiny, they begin to see the world from Remi's perspective, and finally take a stand accordingly. "The poor kid's had a lot to put up with on that beach. We'll give them all a shock when the weather eases up. In the future they're going to get as good as they give"(115). The point is, of course, that they recognize and face the fact that their stalwart defense of Remi is perceived as "shocking" by society at large.

While Remi's friends and family find themselves having to reorganize their world in order to fit Remi into it, she herself is far from untouched. Almost imperceptibly, while others are revising their perceptions of Africans, she is revising her perception of herself as an African. With the passage of time she has become less of a novelty and more closely assimilated into the world of school. It is her relatives in Thornton Heath who first notice the change when she is on the verge of adolescence: "You've been here as long as you been there [Africa]," says Gerald. "You're not a savage any more, it's simple"(122). Recognizing in a confused way some such change in herself, she makes a vow of good behavior on her return to school: "From now on I am going to behave as Miss Bowles says I should, as a perfect ambassador for my race. Except, of course, that I am English now"(123). In fact, without realizing it, she has gradually become more English than the English, developing a superior elocution that her relatives find both intimidating and hilarious and the kind of polite manners that cause her father and uncle to be completely taken aback when, after six years, the family arrives to visit. The two men, having been shown into the school drawing room, Remi greets them with, "How do you do, which one of you is my father?" Remi "preside[s] grandly over the teacups and pass[s] the plates, showing off in front of her visitors, who stare in disbelief.... 'She has become an Englishwoman,' her father says.... 'The transformation has been too complete,' says Uncle Yomi, both laughing hysterically" $(130,131)$.

The transformation is not complete, of course, even in her 


\section{Ethnic Studies Review Volume 22}

father's eyes when he realizes that this is the sum total of her accomplishments, and she still has not received the academic benefits of an English education, for which reason she changes schools. But more importantly, as she comes to realize, the transformation is largely superficial, a point brought home on a school visit to Germany where she reverts to being the object of intense curiosity - a painful reminder of how she is seen by others beyond her own circle whose perceptions she has controlled. "I told Miss Parkes that I felt I was being treated like a freak. Yes, she said, but I was being treated very nicely nonetheless" (163). Outside her immediate circle, it becomes apparent, she will always be considered primarily an African and thus never fully English. This attitude is true even of a group of Jamaican ladies who, as more established residents, impress on Remi that, unlike Africa, "It's just like England in Jamaica"(150). Remi is forced to reconsider in her own mind the extent to which assimilation in English society is either possible or desirable. It increasingly comes to seem at best an illusion, a fantasy fostered by colonialism in order both to underscore the intrinsic superiority and desirability of the "mother country" and its culture and to preserve its exclusivity. The illusion of assimilation would do such by making it ultimately unattainable to outsiders whose marginal and inferior status is thus reinforced and whose own culture is correspondingly devalued often in their own eyes, the very phenomenon that Frantz Fanon described definitively in other words. Remi notes a parallel drawn from Othello, which she is studying at school:

[B]ecause of my public school education and upbringing, I have grown up thinking of myself as an Englishwoman, one of you, Desdemona, but now that I'm becoming an adult I suddenly discover that I am in fact Othello. . . . Othello was destroyed . . . because his marrying Desdemona was seen as an attempt to become a Venetian, and the Venetians could not tolerate this in a black man. It has become increasingly obvious to me that if I do the same thing by trying to become one of you, I am likely to receive the same treatment. All this time l've been living in a fool's paradise and now I don't know who I am. It's a tragedy (172-173). 
The reference to a "fool's paradise" suggests that she has bought into the fantasy of English superiority and admittance to the elite, for her a "paradise" lost along with a personal identity. It would seem that, in her own mind at least, she has come up against an insurmountable invisible barrier. But as her friend says in response to the above outburst, "least now you know who you're not you can begin to discover who you are" (173). There is, it turns out, a way around the barrier by means of redefining its dimensions. As society changes and evolves, so do definitions of what it means to be English.

Kwame Anthony Appiah has remarked in reference to Remi's fellow Nigerians, Wole Soyinka and Chinua Achebe, that their works reveal "the ways in which even those children who were extracted from the traditional culture of their parents and grandparents and thrust into the colonial school were nevertheless fully enmeshed in a primary experience of their own traditions" (Appiah 7). Isolated and surrounded by deeply ingrained assumptions about the savagery of Darkest Africa, Remi has herself assumed that her own primary experience can have no place in any viable adult identity that would enable her to function in contemporary English society. More specifically English national self-identity seems at variance with her own ethnic identity, and thus she has suppressed, often reluctantly, the part of herself that is rooted in Yoruba tradition. But while Remi has been cocooned in the closed environments of school and family, changes have been taking place in the broader society, changes that will fundamentally change what it means to "become one of you." London in particular has seen an influx of new immigrants from all over the Commonwealth, many of them young people in search of a college education who subsequently stay on and settle in England. When Remi arrives to start college herself, she finds herself sharing a house with old friends from Nigeria, plus "Parminder from India, Shirin from Persia and Sylvianne from Belize," all of whom hang out with "mostly Nigerian young men except Jamsher who was Indian, and Kamran from Persia." They do everything as a group, forming households as eclectic in influence as Remi's childhood home in Lagos $(183,182)$. These later arrivals, many of them far less anglicized than Remi, provide a community in which one's primary experience, whatever it 
might be, is considered an integral and valuable component of self identity. "After years of being outsiders the thrill of belonging made us irrepressibly lighthearted"(184). What they belong to precisely is a multi-ethnic society. It is not limited to or barring any specific ethnicity but celebrates the very diversity and difference that has set them indelibly apart from the indigenous population and thus creates a new category of "Englishness" in which one's ethnic origin is both acknowledged and valued and does not preclude full participation in national identity-whatever the rest of the population may think. (The existing, established population is, of course, itself composed of various ethnic groups, a circumstance that the passage of time has tended to obscure.) As Stuart Hall among many others has claimed, everybody is essentially a hybrid. For Remi it becomes possible to be English without relinquishing her formative Yoruba background, with which she finally feels free to reconnect and re-experience. "The wheel had come full circle," she says at the end at a party with her fellow students as she once again becomes a "Yoruba girl dancing" (185).

Her story ends at this point, but it would be a mistake to interpret this as a "happy ever after" ending. While Remi here finds a way to be fully herself, all of herself, in the heart of a formerly alien culture that has ceased to be foreign, she will encounter numerous others for whom she will never cease to be foreign. The more obviously and irrevocably society, especially urban society, becomes multi-ethnic and the more national attention finds itself drawn to this development, the more resistance hardens toward the inevitable change in self-definition (a resistance so far from unique to England as to be almost universal, of course). Hence the need for those of what might be called nontraditional ethnic backgrounds, in English terms, to form their own communities on their own terms, as Remi does, but as a consequence, to remain marginalized for decades. The story told in Yoruba Girl Dancing takes place before the polarization of attitudes has really hardened, but it affords us a glimpse, from a child's perspective, of the genesis of this resistance: it grows out of the necessary changes in perception that I have described as an integral part of Remi's interactions and that have the capacity for mutual enrichment before the point is reached where difference is perceived as 
threatening and the accommodation of difference as loss of control. In small and subtle ways changes in children's games and in adolescent notions of savagery, not to mention adult notions of musicality, exemplify how an established culture does not simply absorb and neutralize an interpolated cultural element, itself remaining intact and unchanged, but is gradually and fundamentally transformed by the encounter. From such small seeds resentment and prejudice grow but so also do opportunities to reinvigorate an austere postwar environment by embracing the infusion of vital new perspectives. As far as the final outcome is concerned, this particular wheel is still in motion.

\section{WORKS CITED}

Appinh, Kwame Anthony. In My Father's House: Africa and the Philosophy of Culture (New York: Oxford University Press, 1992).

Bedford Simi. Yoruba Girl Dancing (New York: Penguin, 1991).

Rich, Adrienne. On Lies, Secrets, and Silence: Selected Prose 1966-1978. (New York: Norton, 1979), 35. 